included in the survey have proved that in 1930 and 1931 the death of migrating smolts was not due to the deficiency of dissolved oxygen but to cyanides, which were frequently found in lethal concentrations. Other poisonous substances, including tar acids, were not found in toxic concentrations and it has been concluded that in the absence of cyanides, migrating smolts would not have been killed in 1930 and 1931. This conclusion marks a distinct step forward, for although several explanations had previously been offered, it had never before been suggested that cyanides were responsible for the death of fish in the River Tees. Another interesting result of the survey is that experiments in the laboratory and on a semi-technical scale have demonstrated that cyanides in coke oven effluents can readily be converted into relatively non-toxic ferrocyanide by treatment of the effluents with spent pickle liquor and lime.

In the non-tidal reach of the Tees, there is only one point at which any large quantity of polluting matter enters and this pollution is derived from sewage. Further downstream, for a distance of about 15 miles, there is no polluting discharge of any importance. A study has been made, therefore, of the effects of sewage pollution on the biology of the river and of the factors which influence the rate of self-purification of a river from pollution by sewage. It appears that temperature is the most important factor, so that the rate of self-purification is much greater in summer than in winter. In determining the relative rates of self-purification under various conditions, it has been necessary to calculate the total quantities of different constituents of the river water from the results of chemical analysis and measure. ments of volumes of water and river flows. The occurrence of certain plants and animals has been correlated with the conditions of the water as determined by chemical analysis and several new and little-known algæ have been discovered. In addition, useful additions to knowledge have been made with regard to the food of fish.

\title{
Cod in Danish Waters
}

$\mathrm{C}$ D are present in all Danish North Sea waters and extend northward through the brackish Baltic Sea into the still more brackish Gulf of Bothnia almost (but not quite) to its northern extremity. Elaborate researches upon the cod in all these waters have been carried out by a Danish investigator, Dr. E. M. Poulsen, the results of which have been published recently in a comprehensive report.*

In Section I of the report data regarding the bathymetric distribution of the fish in Danish waters are given. In the North Sea, cod are most abundant in depths of less than 100 metres. Between 100 and 200 metres they are relatively scarce, while at depths of more than 200 metres they are seldom caught. What few cod there are present in these deeper layers are almost entirely old and large fish. In the Baltic, around Bornholm, cod are most numerous from 40 down to 100 metres, at which depths the water is less brackish than in the overlying layers. In the Kattegat, on the other hand, the fish favour depths of from 40 to 60 metres.

Observations on the spawning periods of the cod in these different regions produced very interesting results. In the Kattegat, spawning begins in February, reaches a maximum in Murch, and finishes about the end of April. In the Belt Sea spawning may extend into the first half of May, while still farther north, in the Bornholm Deep, spawning continues from April until August with June as the main spawning month. Contem. poraneous hydrographical data reveal that the cod spawn in water the temperature of which lies between $3^{\circ} \mathrm{C}$. and $7^{\circ} \mathrm{C}$. The displacement of the

- Erik M. Poulsen. “Biological Investigations upon the Cod in Danish Waters". Meddelelser fra Kommissionen for Danmark Fiskeri-og Havundersegelser. Serie: Fiskeri. Bind IX., Nr. 1., pp. 1-148. C. A. Reitzels Forlag, Kubenhavn, 1931.

No. 3290, Vol. 130] spawning season from early spring far into the summer, on proceeding from the Kattegat into the Baltic, corresponds with the different times at which the bottom waters reach this temperature.

Cod larvæ oceur throughout the whole of the area investigated, but are most numerous in the North Sea, the South West Kattegat, the Sound, Belts, and Western Baltic, and are relatively very much scarcer in the Skagerak, the North East Kattegat, and in the Baltic proper. The larvæ are peculiarly abundant in front of certain marine ridges which intercept the in-going North Sea currents in the Little Belt, at the Gedser Reef, and at Dragden in the Sound. Hydrographical investigations show that the ingoing salt-water currents are largely blocked at these ridges. Larvæ from the North Sea brought in by the currents are therefore largely intercepted by them and accumulate in great numbers on their seaward sides.

During the period 1917-1927 good and bad survival years for the fry are stated to have alternated regularly, the years 1917, 1919, 1921, 1923 , 1925, and 1927 having been good survival years, while the intervening years were bad. The years 1928 and 1929 are described somewhat vaguely as being neither good nor bad but "to some extent normal".

The most interesting and important part of the report is that in which the author records his attempts to determine the causes underlying these annual fluctuations in the abundance of cod fry in these waters. At the outset a certain amount of evidence is put forward which suggests that fluctuations in the number of eggs produced from year to year are not to any appreciable extent correlated with fluctuations in the number of larvæ Iater produced. 
A distinct correlation is found to exist, however, between the temperature of the bottom waters in March-April-May and the quantity of larvæ which can be caught by standard methods in these months, a relatively high temperature being coincident with a good larval yield and vice versa. The reason for this correlation is claimed to be that temperature conditions are directly responsible for the abundance or otherwise of the planktonic food organisms upon which the fry depend for their survival. The radius of action of a tiny cod larva is very small. If it does not find abundant and easily available food as soon as its yolk is used up it dies.

Dr. Poulsen has also found an apparently significant relation between the temperature of the surface water in January and February and the number of larvæ obtainable in the spring months following. The reason for this, he believes, undoubtedly is that when the surface water in mild winters is comparatively warm the winter minimum of planktonic organisms does not sink so far as in more severe winters. (In this connexion it is interesting to recall that in 1927 Johansen found that the number of plaice fry in the Belt Sea was correlated with the number of days in which the water was covered with ice, and the temperature of the surface water in January and February.)

A definite relation is also established between the salinity of the bottom waters in November and December and the number of fry present in the following spring both in the Belt Sea and to a lesser extent in the Kattegat. This correlation, it is pointed out, cannot be due to any direct influence. Spawning does not begin until January at the earliest and larvæ do not appear until about the end of February. The following tentative explanation is therefore put forward. In the autumn an annual migration of large and sexually mature cod is known to take place from outside into the Belt Sea. This migration is dependent upon an autumn inflow of salt water from the North Sea. The larger the inflow, the greater the number of cod which come in with it. Particularly large numbers of eggs are then spawned and a large brood of larvæ results. At the same time, a large inflow of North Sea water produces a condition of high salinity in the Belt Sea and in the Kattegat.

This explanation implies that fluctuations in the numbers of eggs laid produce corresponding fluctuations in the resulting larval broods. This hypothesis may hold good in the Belt Sea but the author himself, in another part of his report, points out that it does not appear to be true as a general rule. It is to be hoped, therefore, that Dr. Poulsen will continue these researches and that this report will in due course be followed by another containing new and illuminating information on these interesting and important points in the life history of the cod in Danish waters.

G. A. S.

\section{Low Altitude Auroræ}

$A \mathrm{~N}$ unusually low aurora was witnessed on A March 8 of this year at the Auroral Observatory, Tromsø, Norway. The height was determined photographically by the Director, L. Harang, working with Dr. W. Bauer (of the Photophysical Laboratory, the Danzig Technical High School), who have made a brief joint report of their work in Gerlands Beiträge zur Geophysik (Bd. 37, pp. 109-115, 1932). At the suggestion of $\mathrm{E}$. Brüche, Berlin, two film cameras were in use at the two base stations (43 km. apart) from which simultaneous parallactic photographs were made; this was in order that, by taking short exposures of a few seconds, a continuous record of the development and changes of auroræ might be obtained. On the two evenings of March 8 and 9, 1932, about 500 pairs of photographs of bows, bands, draperies and rays were taken, during intense displays of the northern lights. A series of 20 pairs of these pictures, covering a period of only 75 seconds, on the night of March 8, disclosed a particularly interesting phenomenon.

At 20.45 G.M.T. an intense yellow-green auroral bow with a deep-red lower edge appeared in the north, at an elevation above the horizon of about $13^{\circ}$; it was found to be $290 \mathrm{~km}$. distant, at an altitude of $77 \mathrm{~km}$. Within 40 seconds it drew southwards by $20 \mathrm{~km}$., and penetrated the atmosphere further, to $75 \mathrm{~km}$., while its eastern portion dissolved, so that the bow ceased to be in the field of the camera. Suddenly, during a few seconds, another bow developed, $20 \mathrm{~km}$. behind the first, that is, at the distance where the latter originally appeared; the second bow, however, was lower, its measured height being only $65 \mathrm{~km}$. After 15 seconds its height quickly increased to $80 \mathrm{~km}$., and it receded to $350 \mathrm{~km}$. distance, while the red colour vanished from the lower edge. This bow also then drew slowly southwards, while its right end rose to $100 \mathrm{~km}$.; this disclosed a third faint bow, lying at $90 \mathrm{~km}$. height and $70 \mathrm{~km}$. behind the second one, the gradual southward motion of which it followed. The time during which the second bow was below $75 \mathrm{~km}$. was less than 20 seconds.

The outstanding character of this observation is well illustrated by the diagram here reproduced (Fig. 1), from the paper referred to. In column $A$ are shown all the measured heights of the yellowgreen auroral bows observed at Tromsø during the period February to October 1929. In the middle column $B$ are shown the heights of the red-edged yellow-green bows observed there on March 8, and in column $C$ the heights of other yellow-green bows observed on the same evening. The diagram shows that the heights usually exceed $90 \mathrm{~km}$., but, rather rarely, come down nearly to $80 \mathrm{~km}$., as Prof. C. Størmer found. The quite exceptional nature of the lower red-edged 